\title{
Chuck Roland, leading Canadian medical historian, dies
}

Published at www.cmaj.ca on June 16, 2009. Shortened for print on July 9, 2009.

$\mathrm{D}$ r. Charles (Chuck) Gordon Roland, a medical historian and award-winning writer and editor with 33 books and nearly 500 articles, editorials and reviews to his credit, died on June 9, 2009 at the age of $76 . \mathrm{He}$ is survived by his wife, Connie, their 7 children and 10 grandchildren.

Roland spent his early years in a $\log$ cabin at God's Lake, in northern Manitoba, until his father died. His mother worked hard to support the family and they moved frequently around the North.

After undergraduate studies at the University of Toronto, Roland graduated from the Manitoba Medical College in Winnipeg in 1958, with the prize for the best all-round record. Following internship, he entered family practice in Tillsonburg and Grimsby, Ontario, but found the work unsatisfactory. He inquired about a possible position at CMAJ, but there wasn't one available. However, the editor suggested he apply to JAMA instead. In 1964, Roland was hired as one of its senior editors and spent 5 years honing his writing and editing skills.

In 1969, Roland was recruited to the Mayo Clinic in Rochester, Minnesota, where he was executive editor of the Mayo Clinical Proceedings and developed many of the clinic's publications. He became president of the American Medical Writers Association in 1969.

In 1977, Roland returned to Canada as the inaugural Jason A. Hannah Professor of the History of Medicine at the new McMaster University medical school in Hamilton, Ontario. Roland served as president of the Canadian Society for the History of Medicine and as editor of its Bulletin. He also continued to write articles for the popular press and scholarly journals, and produce books. Roland's account of medical services in the Warsaw ghetto, Courage Under Siege: Starvation, Disease, and Death in the Warsaw Ghetto (1992), was awarded The Royal Society of Canada's Jason A. Hannah Medal for medical history.

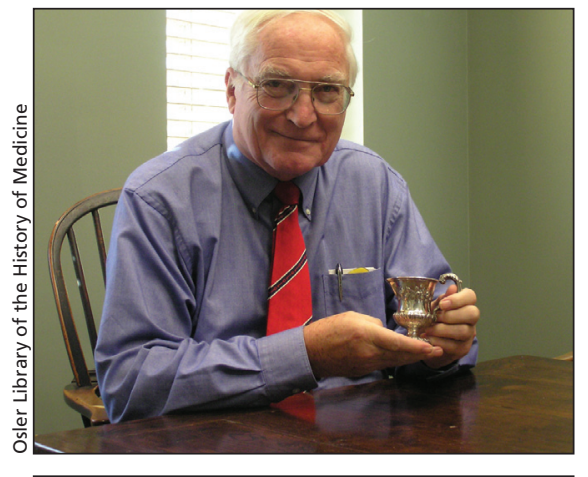

Dr. Charles Roland holds a cup that was presented to Grace Osler Abbot following the death of Revere Osler in the First World War. Revere was Grace and William Osler's only child.

Roland's most recent biography, Noted Surgeon, Fine Citizen: The Life of Archibald Malloch, MD 1844-1919, is thoroughly researched and lucidly written. Malloch's close friendship with Dr. William Osler made him a natural subject for Roland who considered Osler his role model and had a passionate interest in his life and writings. In addi- tion to penning many original essays, Roland wrote or edited 11 compilations of Osler's writings. He was also a founding member of the American Osler Society and greatly enjoyed its congenial annual meetings.

When awarded an honorary degree in 1997 by his alma mater, Roland attributed any success he had in his career to Osler's watchword "work." Not that Roland was a workaholic, but rather he had a disciplined approach to work that made him so productive.

Canada has lost a great advocate for its history in medicine.

\section{Peter Warren MA MB \\ President \\ Canadian Society for the History of \\ Medicine \\ Winnipeg, Man.}

The author acknowledges the use of a transcript of an interview with Chuck Roland conducted by Hannah Professors Paul Potter and Jacalyn Duffin. Details about the transcripts can be found at www.cshm-schm.ca/news_item.php?id=33

\section{More humanities at cmaj.ca}

The heart resuscitated, with poetry: Poet and physician Shane Neilson demonstrates his fine ear for language and subtle, lyrical take on everyday life, in the free-verse poems published in Exterminate My Heart (Frog Hollow Press, 2008). Whether he's writing about red hair or "shutters rustling", he engages the readers by grounding his poems in the real world. - Mark Frutkin, Ottawa, Ont.

Guide to Aboriginal people's health: The essay collection, Healing Traditions: The Mental Health of Aboriginal Peoples in Canada (UBC Press; 2008), argues that when indige-

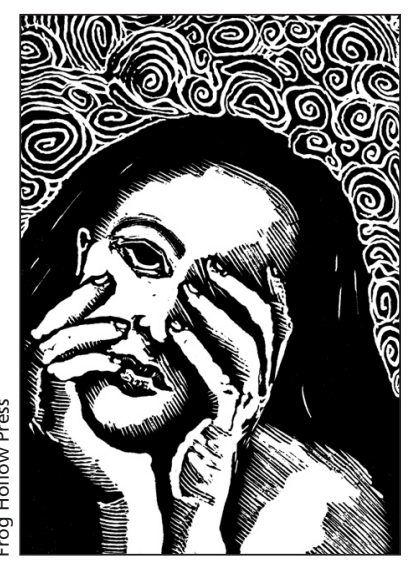
nous peoples shape their own treatment programs efficacy is greatly enhanced. Coedited by the late Gail Guthrie Valaskakis (an Aboriginal) and Laurence J Kirmayer), Healing Traditions is timely and useful. — Jennifer Dales, Ottawa, Ont.

DOI:10.1503/cmaj.091270

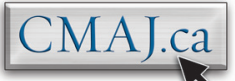

